\title{
Política de las imágenes: hacia una praxis docente para el sistema de la visualidad contemporánea
}

\author{
Juan Manuel Pérez ${ }^{(1)}$
}

Resumen: Este trabajo tratará de ensamblar distintos recorridos pedagógicos generando conceptos e integrando experiencias que marcan la necesidad de repensar los paradigmas de la educación visual desde un punto de vista abierto e interdisciplinario.

Palabras clave: Didáctica de la visualidad contemporánea - Fotografía y praxis histórica - medios gráficos - procesos educativos de subjetivación - Iconósfera contemporánea phatos visual - soma visual.

[Resúmenes en inglés y portugués en la página 191]

(1) Profesor y Licenciado en Letras (UBA), Especialista en Capacitación en Lenguajes Visuales (Motivarte). Docente de análisis visual y estudios culturales en diversas instituciones. Director de Estudios de la Escuela de Fotografía Motivarte. Traductor y Poeta.

\section{Introducción}

Este trabajo tratará de ensamblar distintos recorridos pedagógicos generando conceptos e integrando experiencias que marcan la necesidad de repensar nuestros paradigmas de la educación visual desde un punto de vista abierto e interdisciplinario consciente de su propio contexto social y tendiente a otorgar lugares de reflexión crítica a estudiantes en el ejercicio del pensamiento y la práctica artística. Principalmente visual, gran parte de esta tesis fue elaborada gracias al intercambio con estudiantes y docentes de la escuela de fotografía, del bachillerato popular, y de los distintos ámbitos educativos formales $\mathrm{e}$ informales donde participo.

En esas asignaturas me permití pensar individualmente y colectivamente propuestas que pude dividir en tres tipos de fundamentación: la alfabetización en el Sistema de la Imagen Contemporánea, el ejercicio del pensamiento crítico de las imágenes que funcionan como documentos de la historia y el empoderamiento que se le otorga a la clase por intermedio del debate. En la lucha por la argumentación y en el coro de voces que aparecían en el espacio áulico al poner en tela de juicio nuestras propias prácticas cotidianas tanto visuales 
como discursivas o, incluso, las implicancias que estas tenían oí la necesidad de pensar una praxis docente anclada en nuestras problemáticas sociales.

Para teorizar mi experiencia donde el escenario era el reconocimiento colectivo de la complejidad de las imágenes de la visualidad contemporánea me vinculé fuertemente con autores como Alfredo Jaar, Roman Gubern, y el inefable Roland Barthes. Estas perspectivas dieron como resultado el primer capítulo de este ensayo, titulado La construcción del aula como ágora de debate, que interpreta el espacio de mediación entre estudiantes y docentes como un ágora de reflexiones que necesita un marco teórico de reconocimiento para las imágenes que se encuentran en la visualidad contemporánea frente a nosotros, contra nosotros, y que codifican y construyen distintos niveles de subjetividad afectando la identidad de quienes formamos y de quienes se forman dentro de la misma esfera de imágenes. En una segunda instancia donde lo que se ponía en cuestión era la propuesta de que lo que vemos, nos mira, los autores fueron Eduardo Cadava, Georges Didi-Huberman, Ticio Escobar y el inefable Walter Benjamin. Esto me llevó a la escritura del segundo capítulo, titulado Lo que vemos nos mira, que coloca en escena un pedagogía de lo no visible a través del análisis coral de la constelación de artistas que trabajaron la frontera de la representación a través de soportes visuales, arrojando como hipótesis una lectura de las imágenes del soporte álbum familiar devenidas en documentos de la historia reciente de nuestro país. Finalmente Jacques Ranciére y Graciela Frigerio fueron mi sustento para el tercero de esos pilares donde movilicé las lecturas anteriores dentro de la esfera social que compartimos docentes y estudiantes, recuperando sus voces y ámbitos buscando formas nuevas de vida para el convivio que es la pedagogía. Y así es como el tercer capítulo, titulado Desde el espectador emancipado hacia el estudiante emancipado, desarrolla una puesta en práctica de una política de la imagen como factor decisivo para la construcción de una comunidad crítica y que, a la vez, mantenga una relación pendular con lo teórico y lo práctico a partir de una pedagogía de la emancipación. Al término de los capítulos enumeré una selección de actividades de manera propositiva que me sirvieron para movilizar aquellas temáticas. Teniendo en cuenta este punto de partida desarrollaré cuán definitivo para quien quiera ejercer la docencia es tener una reflexión acerca de las distintas subjetividades que conforman las distintas iconósferas donde nos movemos, qué tipo de prácticas docentes imponen, y cuáles niegan.

\section{La construcción del aula como ágora de debate. Elementos conceptuales para reconocer y deconstruir la visualidad contemporánea colectivamente.}

¿Cómo abordar dentro del aula las problemáticas de la imagen contemporánea? ¿Cómo poner en tensión el contenido formal y la carga simbólica de las imágenes que circulan por distintos medios en la plataforma de imágenes en la que nos movemos? ¿Cómo delimitar y evidenciar distintas atmósferas de imágenes? ¿Cómo generar en el marco de una materia de análisis visual, los elementos para la construcción de una comunidad crítica, una identidad reflexiva atenta a los modos de representar a partir de la lectura de imágenes? 
Y más: ¿Cómo comprender la época actual a través de las imágenes que conforman nuestro imaginario ya que son acaso síntoma o significado de nuestro tiempo? ¿Cómo develarlas, cómo denunciarlas? Distintos autores: Walter Benjamin, Susan Sontag, Guy Debord, Giovanni Sartori, entre otros, postulan que esto es imposible. No creen en la posibilidad de que la imagen pueda ayudarnos a interpretar el mundo. Es decir, afirman que no podemos acceder al conocimiento de la realidad a través de ellas porque el Sistema de las Imágenes es parte de un aparato demasiado naturalizado que no podemos quebrar ${ }^{1}$.

Veamos cómo se desarrolló esta idea: Walter Benjamin amenaza que a través de la reproductibilidad técnica de las imágenes, los espectadores corren peligro de convertirse en máquinas de registro y grabación de imágenes, lo sostiene por intermedio de una analogía: las técnicas de sujeción y dominación de masas vacían de identidad a los individuos así como la reproducción de imágenes las vacía del sentido artístico de la tradición al quitarles el aura.

La violación de las masas, a las que el fascismo pone de rodillas con su culto al Fhürer, se corresponde con la violación de todo mecanismo puesto al servicio de la fabricación en masa de valores culturales (...) desvinculados del ámbito de la tradición cultural de occidente (Benjamin, 2010).

Al no ser entendida ya en términos de los valores tradicionales de singularidad y originalidad, la fotografía y el cine como obras de arte masivas pertenecen ahora a una red de relaciones mediadas de manera imprevisible que, al encontrarse con un aparato de registro, pierden su identidad tradicional.

Continuando este planteo contra tecnológico, Guy Debord en La sociedad del espectáculo, postula que a través de la incesante renovación tecnológica se produce la fusión económica entre lo público y lo privado, la imposición de un verosímil que no admite réplica, y la abolición de la memoria. De esta manera comienza su proclama,

Toda la vida de las sociedades donde rigen las condiciones modernas de producción se manifiesta como una inmensa acumulación de espectáculos. Todo lo que antes se vivía directamente, se aleja ahora en una representación (...) Las imágenes desprendidas de cada aspecto de la vida se fusionan en un cauce común donde la unidad de esta vida es ya irrecuperable. La realidad vista parcialmente se despliega dentro de su propia unidad general como pseudomundo aparte, objeto de mera contemplación (Debord, 2012).

Distinto a ellos, el filósofo francés Jacques Ranciére se pregunta en "El teatro de las imágenes" una serie de cuestiones que apuntan a otra conclusión, la posibilidad de dejar de ser consumidores pasivos de imágenes para devenir en lectores activos de imágenes,

¿Es posible hoy la reflexión crítica? ¿Es posible hoy, a través de la imagen, la resistencia política, el disenso? ¿O el exceso y la sobreabundancia de las imágenes (de ciertas imágenes las que no se suprimen) embotan esas capacidades hasta reducirlas a una simple ilusión o un ejercicio vacío? ¿Pueden las imágenes del 
sufrimiento, transformadas a su vez en mercancías y en íconos más bien publicitarios, exceder los cauces que las integran a los circuitos mundiales del mero consumo, al desecho casi instantáneo, a la indiferencia ética y política? ¿Hay posibilidades, por tenues que sean, de crear un espacio en que las imágenes generen una respuesta genuinamente crítica? ¿Hay posibilidades de ser otra cosa que consumidores de imágenes previamente seleccionadas por otros? (Ranciére, 2007).

A estas preguntas, Ranciére afirma que sí. Y más, confirma su esperanza en la serie de obras del artista chileno Alfredo Jaar sobre el genocidio en Uganda. El disenso, para él, es un acto político que busca modificar las coordenadas de lo visible. En el arte el disenso vuelve a hacernos pensar y vuelve a hacernos ver: en fotografía hace aparecer imágenes donde no las había, en literatura hace resurgir las voces de quienes fueron acallados, en el cine hace presente como cuerpos figurantes a las clases marginadas, en ambos casos recupera el lugar de las minorías. El disenso construye un nuevo espacio ético. ¿Podremos construirlo nosotros en nuestras clases?

Una buena manera de comenzar un análisis sobre las imágenes que nos circundan es identificando un objeto de estudio y la problemática que plantea su campo de análisis. Detengámonos en la manera en que la plataforma visual construye regímenes de visualidad y regímenes de subjetividad, es decir, en la manera en que construye nuestras identidades, proyecta estereotipos y estigmatizaciones sociales.

En todos los espacios de la vida cotidiana nuestra cultura se caracteriza por el predominio creciente de lo visual. Esta plataforma de imágenes y de imaginarios se presenta frecuentemente como un fenómeno natural aunque se trate de una construcción completamente codificada cuyo régimen visual, es decir su Régimen Escópico ${ }^{2}$, se fue conformando a lo largo de siglos de visualidad iconográfica y que tiene su auge a partir del comienzo de la modernidad. En la actualidad, la cultura visual en la que vivimos consta de un continuum entre las artes visuales y las imágenes de los medios de comunicación: todas esas imágenes componen hoy nuestra iconósfera.

¿Cómo incluir, entonces, dentro del armado de una clase sobre la imagen contemporánea distintos anclajes educativos, filosóficos y sociales para poderla aprehender y comprender desde todas sus aristas? ¿Cómo poner en evidencia que existe una construcción social de lo visual y a su vez una construcción visual de lo social?

Roman Gubern, dirá que para desmantelar los códigos de la iconósfera en que vivimos es necesario construir una alfabetización visual que sea consciente de una alfabetización artística y social. Hay distintas herramientas de esta alfabetización artística que queremos complejizar, y que conforman un mapeo para comprender las imágenes que vemos, que están ligadas con nuestros modos de ver y son dependientes de la iconósfera en la que nos movemos. Estas herramientas son: 1) la identificación de una iconósfera como marco visual, 2) el análisis de su aspecto pathetico, emparentado con lo trágico de la imagen, 3) el análisis de su aspecto somático, emparentado con lo corporal de la imagen humana, 4) el análisis de su aspecto emparentado con la praxis fotográfica. Analicemos estas herramientas: 


\section{1) Iconósfera}

Como ya fue mencionado, a la esfera plástica de imágenes en medio de la cual nos movemos cotidianamente y sobre la que pesan los distintos mensajes ideológicos, culturales, morales, o publicitarios, la podemos denominar como iconósfera. Esta plataforma está cargada con mensajes ideológicos, morales y de clase que fundan sobre el sistema de las imágenes claros regímenes de poder simbólico. Siguiendo el análisis que Gubern propone con respecto al origen de este entorno imaginístico artificial ${ }^{3}$, podemos ubicarlo durante el proceso de industrialización de las grandes ciudades, a la par siempre del avance de los saberes técnicos de la época ${ }^{4}$,

La iconósfera se habría constituido en las sociedades industrializadas durante un siglo que había asistido al invento de tecnologías de la imagen como la fotografía, la litografía, el cartel, el fotograbado, la narrativa dibujada de los comics, y el cine, medios que densificaron espectacularmente el capital icónico en los espacios privados y públicos de las sociedades urbanas (Gubern, 1996).

Podemos pensar la iconósfera, entonces, como la estructura visual plástica ${ }^{5}$ donde se asienta el capital icónico de una sociedad. Esta estructura está determinada siempre por los modos de ver de cada período histórico y también por los modos de ver que cada sociedad construye.

Como la iconósfera emparenta lo social con lo artístico y lo cultural, cada sociedad conforma su propio régimen visual, es decir, su propio sistema de imágenes y evidencia así una determinada construcción social de lo visual. Cada régimen visual entrena un tipo de ojo determinado que está dispuesto a codificar determinados símbolos sobre las imágenes. Cada régimen visual organiza un imaginario visual determinado. La imagen, lo sabemos, es polisémica (poli: muchos; sema: significado), y no se revela a todos de la misma forma. Para visibilizar a la iconósfera, este campo de imágenes que hace confluir la tríada de imaginarios social, artístico y cultural, es necesario el entrenamiento crítico que distintos métodos y disciplinas de análisis del pensamiento contemporáneo otorgan. En esta dirección, la semiología, la antropología de la imagen, el análisis de su discurso, la filosofía de la imagen, la ética de la imagen, comprenden un sistema que permite deconstruirla.

\section{Phatos: Las emociones en la imagen}

La densidad de la iconósfera nos habla también de su carácter turbador y fronterizo entre los parámetros de lo simbólico y de lo real, entre las delimitaciones de lo conceptual y de lo concreto, entre los umbrales de lo mágico y de lo existencial (Niedermaier, 2013). La imagen existe más allá de donde se presenta o de donde la encontramos, existe en un plano emocional: genera amores y rechazos, filias y fobias. Mirar no es simplemente ver, mirar es implicarse.

La palabra patético tiene una muy larga historia que es interesante hacer subir a la superficie, como lo haría un arqueólogo con una antigua ánfora griega enterrada, y es la de la 
palabra y el concepto de pathos, central para las tragedias griegas y fundamentales para comprender qué tan cerca del plano de las emociones están las imágenes ${ }^{6}$.

La imagen, sabemos, es una de las principales herramientas para la construcción de identidades dentro de una sociedad. Condensa pensamientos, sueños, recuerdos e idealizaciones positivas o negativas ${ }^{7}$, es decir, espesores de sentido (Niedermaier, 2013). En este sentido, Gubern asocia a la imagen a un juego de espejos: "las imágenes, cuando no constituyen espejos (incluso deformantes) de la sociedad que las ha creado, suelen construir espejos elocuentes de sus imaginarios, de sus deseos y sus aspiraciones, de sus sueños reprimidos o prohibidos" (Gubern, 2004).

Nosotros construimos las imágenes pero las imágenes también nos construyen a nosotros: imponen modos de conducta, condicionan experiencias y puntos de vista e incluso tratan de modelar cuerpos y sujetos, proponen una realidad existencial. Constituyen altares.

No olvidemos, como dice Roman Gubern de nuevo: "su poder para despertar la ira, la pasión, el escándalo, la emoción violenta, posibilitando la manipulación a través de la publicidad y la propaganda. Las imágenes enojan, emboban, seducen, atacan. Y no lo hacen con inocencia" (Gubern, 2004).

La imagen contemporánea (y determinados géneros fotográficos como el documental o el fotoperiodismo) pone en funcionamiento el Pathos dentro de la imagen. Didi-Huberman se refiere al grado de patetismo que las imágenes cargan como la posibilidad de quemar,

Queman con lo real, queman con el deseo que animan, con la intencionalidad que la estructuran, con la enunciación, incluso con la urgencia que manifiestan, queman con la destrucción, por el incendio que estuvo a punto de pulverizarlas, por eso la importancia del archivo, queman por el brillo, es decir, la posibilidad visual abierta en su consumación, precios y pasajera, queman con su movimiento intempestivo, incapaz de detenerse en el camino, queman con su audacia cuando vuelven imposible todo retroceso, queman por el dolor de donde han surgido y que ellas a su vez producen en quien se tome el tiempo de involucrarse (Didi-Huberman, 2007).

Las imágenes son especies de prismas en los cuales se concentran muchas cosas, destaquemos entonces su posibilidad para generar conmociones, transformaciones en sus espectadores ya que son más que simples manifestaciones, son signos, son expresiones comprendidas dentro de un lenguaje codificable. Didi-Huberman, aquí, está pensando en la capacidad de generar una alerta de disenso a partir de una imagen cargada de Pathos y producir una revuelta social al poner en escena pública lo censurado, lo trágico, lo miserable.

También Susan Sontag realiza a través de las imágenes que se publicaron de la guerra de Afganistán una pormenorizada cartografía del dolor en Ante el dolor de los demás. Ella observa que el problema no es que la gente se acuerde de los crueles o miserables acontecimientos militares a través de las imágenes, sino que solamente se acuerden de las imágenes que vehiculizan la información de los acontecimientos, "las fotografías desgarradoras no pierden forzosamente su poder de impacto. Pero no ayudan mucho si lo que pretendemos es comprender. Los relatos pueden llevarnos a comprender. Las fotografías hacen otra cosa: nos atormentan" (Sontag, 2004). 
Por otra parte, Henri Bergson considera a las emociones como gestos activos que se expresan de la misma manera dentro de una comunidad en determinado momento, idea que retomaría el historiador Aby Warburg al desarrollar su concepto de pathosformel, en el trazado de una genealogía de las formas de lo patético a través de la historia del arte occidental. Podemos seguir, por ejemplo, una línea diacrónica decimonónica de expresiones a partir de Rodin que se consolidaría en "El beso" del fotógrafo Alfred Eisenstaedt.

Como vimos, hay un vínculo muy fuerte entre la figura (la imagen) y la existencia (la realidad). Podemos hablar de una realidad existencial en la imagen. Recordemos que cada religión tiene también su propio sistema de imágenes. En 1554 en Trento, al norte de Italia, un grupo de obispos se reunió durante todo un año para debatir si La Divinidad debería ser representada o no. Un grupo pensaba que por su alto grado de sacralidad no debía ser representada por artistas. Otro grupo pensaba que por su alto grado de sacralidad debía ser representada infinitamente sin cesar. Esto ocasionó una división que todavía continúa entre iconofílicos e iconofóbicos. Los primeros estaban a favor de los murales en las capillas y catedrales, los segundos quemaron y destruyeron toda representación divina y censuraron violentamente a cualquier artista que se dedique a hacerlo. Este es un caso ejemplar, pero la historia está cargada de ellos. ¿Qué estamos dispuestos a ver en nuestras imágenes?

\section{Soma: El Cuerpo en la imagen}

La cuestión del cuerpo puede ser tratada por partida doble en cuanto a la imagen, en primer lugar, solamente si tenemos cuerpo, ojos, podemos acceder a las problemáticas de la representación, el hecho de ver es una cuestión física y fisiológica, no vemos todos lo mismo; por otra parte el hecho de mirar es una cuestión de paradigmas culturales, no vemos todos lo mismo. Desde la educación visual podemos contribuir a realizar un abordaje crítico del surgimiento del cuerpo como un dispositivo fuertemente semióforo, abierto y dinámico.

No podemos entender las figuraciones culturales artísticas del cuerpo bajo la dinámica de una lectura lineal. No registra una isotropía, un solo camino de lectura, el cuerpo es una realidad plural con yuxtaposiciones, como resume el Barthes de El placer del texto, se lo recorre como a las vetas de una madera, y es en los límites donde se produce el sentido de la obra. Es en las yuxtaposiciones, en las deconstrucciones y en sus emplazamientos donde funcionan las heterotopías del cuerpo entendido como el espacio propio del siglo XX que genera subjetividades.

En ¿Qué es un dispositivo? Giorgio Agamben (2014) hace una pequeña genealogía sobre el término y, en un análisis muy cercano al de Michel Foucault, postula que el régimen social que produce procesos de subjetivación alienada cuya estructura sostiene un discurso hegemónico de la verdad puede llamarse "dispositivo". Un dispositivo, entonces, ante todo es una máquina de reproducción social que produce subjetivaciones y también es en consecuencia una máquina de gobierno (Agamben, 2014). Entender el cuerpo, a su vez, como un dispositivo de desubjetivación lo convierte en un arma artística de subversión, un arma de disidencia. Es decir, de desnaturalización: no una máquina de gobierno sino de insurgencia. 
El análisis de cómo piensa la política y el lugar preponderante en distintos regímenes estéticos el dispositivo visual llamado Cuerpo en determinados artistas de la iconósfera contemporánea puede ofrecerse como un itinerario representado como espacio de contigüidad, de topografías, de contornos, de proyecciones sobre cómo una comunidad lo imagina y como esas fantasmagorías devuelven a la comunidad una unidad de sentido estético y político; ilumina, además, un territorio clave de contraposiciones y paradojas (tecnológicas, políticas, territoriales y jurídicas ya que es en el estatuto de los cuerpos donde se aplica el "hacer vivir" foucaultiano de una sociedad) y se muestra como un terreno de indagación sobre las propias condiciones históricas en donde se materializa el acervo cultural de lo contemporáneo. Todo se debate ahí: entre el cuerpo material elaborado por los artistas y el espacio subjetivo e identitario que le asignan al individuo y la comunidad. En esta dirección, proponer en el ágora áulica, en el espacio de voces que configura una clase, las posiciones, ideas y realizaciones de artistas como Jenny Saville, Ana Mendieta, Francis Bacon, Olivier de Sagazan, Gina Pane, Wafaa Bilal, Orlan, Natacha Voliakovsky, Nicola Costantino, Juan Dávila o Susy Shock nos acerca a reflexiones no sólo sobre qué idea tenemos sobre nuestros cuerpos, sino también qué ideas políticas, sexuales y filosóficas construye el arte sobre ellos, es decir sobre nosotros.

¿Qué señala esta potencialidad indeterminada de las figuraciones del dispositivo cuerpo? En su análisis sobre la emergencia de discursos y poéticas transgresoras en la cultura brasileña, Mario Cámara plantea un doble efecto como respuesta y que podríamos resumir de esta manera: por un lado su condición de artificialidad: nada es natural, siempre hay una alineación, un entramado, un proceso de subjetivación hegemónico sobre él; por otro lado y como consecuencia, su permanente estatuto de alucinación y transgresión. Esta noción espectral de un cuerpo político y estético conduce nuestra mirada sobre el pasado y nos obliga a preguntarnos por las herencias, porque hurgar en una herencia o en un archivo también es producir sentido, y esto implica un movimiento de liberación de voces, de historias, de subjetividades. En su lúcido libro sobre la carne como figura de la historia, la ensayista Alicia Montes se preguntó si en aquello no simbolizable que existe en los imaginarios de la comunidad y que retorna como calamidad peligrosa, degenerada, atenta contra los estatutos artísticos establecidos, dispuesta para deconstruir binarismos, lista para a reposicionar en el centro del canon estético de la materia los cuerpos trans, alterados, deconstruidos, puestos en cuestión, no hay una herramienta para leer los sentidos de la violencia contemporánea y no nos da, acaso, los materiales insurgentes para construir una comunidad crítica ya que originan nuevas formas de contar la historia y de vivir nuestras nuevas subjetividades.

\section{Praxis: la estrategia de visibilizar}

Centrémonos ahora en la obra del artista chileno Alfredo Jaar para analizar la manera en que una obra desarrolla el rol crítico de una praxis fotográfica y quiebra el ámbito de la contemplación. Consultado sobre la mega exposición arquitectónica en torno a la conocida imagen de Kevin Carter en Uganda, Jaar respondió que, 
Esta obra es un teatro construido para una sola imagen. Cada imagen contiene una concepción del mundo: en 8 minutos el espectador permanece en esta estructura y se le ofrece las herramientas para comprender que una fotografía no se toma: se hace. Es decir, cuando uno toma una fotografía el fotógrafo tiene que tomar una serie de decisiones que impactan en el resultado (Jaar, 2014, el subrayado es propio).

En la misma entrevista Jaar reflexiona sobre su obra como ejercicios de pensamiento, notas sobre papel que yuxtaponen o imbrican información al campo visual y que articulan conclusiones manifiestas sobre el impacto de su utilización. Jaar nos demanda que le demos sentido a toda la información visual que manejamos, y este es un señalamiento tanto para el artista como para el docente "es necesario - dice, entrevistado nuevamente por Griselda Pollock- bajar el ritmo, contextualizar de manera precisa cada imágen, encuadrarla para que tenga sentido y no se la pase por alto (...) para representarlas de manera que tengan sentido" (Pollock et. al 2012, 109, el subrayado es propio).

¿A qué se refiere Jaar con su idea de tener sentido? ¿Qué movimientos o qué repercusiones tiene que tener la obra para producirlo? En sus obras, suspende las imágenes que lo atormentan y las sustituye por textos, ofreciendo ausencias que provocan presencia y que, a la vez, ponen de relieve la praxis de quien hace la imagen y el convivio de quien la recibe. En sus obras no vemos un autor como productor sino que vemos al autor como curador y denunciante, pasando a la acción sobre el contenido visual que nos muestra o nos suprime. Así Jaar trabaja tanto con la crisis de representación como con el problema del testimonio de lo trágico para poner en evidencia las contradicciones éticas de la mera contemplación del espectador.

En su libro sobre los radicales cambios que sufrieron conceptos como la autonomía y la mímesis en el arte, Ticio Escobar, ferviente defensor de la curaduría como ejercicio crítico, anuncia el giro ético del arte contemporáneo que se ejecuta por intermedio de aquellos artistas comprometidos al integrar en sus obras elementos de extramuros como resto, excedente o remanente contaminado de sentido. En esta misma línea está Jaar cuando enlaza en sus obras iconósfera, medios, soma y pathos,

Cuando el arte deja de basar sus argumentos en los puros valores de la forma y logra desencastrar la circularidad de su propio lenguaje y abrirlo a la intemperie de la historia, de sus vientos oscuros y sus turbios flujos, entonces sus pulcros recintos se ven saludablemente contaminados por figuras y discursos, textos, cuestiones y estadísticas provenientes de extramuros (Escobar 2015, 67).

Para Theodor Adorno la experiencia estética implica ser atrapado por la irracionalidad de los momentos sensibles que la obra propone pero, inmediatamente, surge una pregunta sobre el carácter doble que desplaza al espectador de ese primer momento para ubicarlo en un terreno que lo lleva a reflexionar sobre esa experiencia. "El arte-dice- es y no es para sí; la obra se encuentra emparentada con el mundo gracias al principio que la opone a este". Jaar quiebra este ser para sí, esta autonomía estética de la imagen y se pregunta qué puede hacer el arte ante las situaciones extremas y reubica al espectador en una relación 
activa con lo que hoy debemos ver y comprender, y ante lo cual reaccionar. En sus instalaciones propone un movimiento que va de la estética hacia la praxis, empuja al espectador para que reflexione sobre su propia distancia, sobre su propia condición de ver y entender. Este movimiento hacia la praxis fotográfica repercute en las condiciones mismas en las que él difunde las imágenes agónicas con que trabaja. Martha Rossler, en su conocido trabajo Brining the war home trabaja sobre el mismo efecto: hacer de la contemplación una praxis política. La experiencia de la contemplación, entonces, se rehace y modifica nuestra propia subjetividad.

En una cultura saturada de imágenes y estructurada por una relación de continuum visual, la obra de Jaar produce un acercamiento entre el espectador y el denunciante. "Una foto no se toma: se hace" sentencia Jaar, y en las instalaciones que hace, la política de las imágenes que construye reconfigura las propias historias de los y las víctimas: no podemos ya ser espectadores.

Praxis, Soma, Pathos, son elementos conceptuales del discurso visual de nuestra Iconósfera, como docentes debemos entender estos elementos como herramientas prácticas de exposición y presentar al panorama actual de la visualidad no como un decorado estético sino como un escenario de constantes batallas donde se desarrollan mecanismos que conforman modos de ver para nada inocentes. Nuestras posiciones sumadas a los debates dentro del ágora áulica, dinamitan sucesivamente el sentido de lo visual como construcción social.

\section{Actividades propuestas:}

1. Debate inicial sobre "En la Caverna de Platón" de Susan Sontag. Si todo sucede para quedar en una foto ¿hay algo fuera del sistema de las imágenes?

2. Definición de Disenso ¿qué fotógrafos conocen que compartan esta característica?

3. Jaar vs Google: Dice el artista Alfredo Jaar que las imágenes de los genocidios en Uganda fueron ocultadas. ¿Qué imágenes de Uganda nos devuelve el buscador de google?

4. Iconósfera: Todo lo que podamos leer de Roland Barthes es beneficioso para la salud, sea sobre la imagen (Mitologías, El sistema de la moda, La Torre Eiffel, La cámara Lúcida, etc) o sobre semiología (Elementos de Semiología, El imperio de los signos, El susurro del lenguaje, Fragmentos de un discurso amoroso, etc). En "Retórica de la imagen" pone de relieve elementos estructurales de la imagen que comprenden y organizan un sistema y que nosotros podemos reconocer a partir de la publicidad de la pasta Panzani: un sistema de imágenes organizado con colores, formas y mensajes afines a la italianidad (lo formal se presenta demarcado y lo figurativo se presenta connotado). Confrontemos con las publicidades de la empresa japonesa Tarako para ver qué rápidos son los quiebres en los códigos formales que se denotan y los que connotan otras iconósferas. ¿Por qué? ¿Reconocemos qué vende la marca? ¿Compartimos algo con los receptores de esta publicidad? ¿Reconocemos un código de connotación? ¿Qué otro ejemplo conocen? Veamos ahora la publicidad "Dame otra piña" de la marca Piña Colada.

5. Pathos: Como ya vimos, la imagen es una de las principales herramientas para la construcción de identidades dentro de una sociedad, condensa pensamientos y latencias (como en Potencial de Ananké Asseff), sueños y represiones (como en Los Sueños de Grete 
Stern), rastros culturales y despojos históricos (como en Restos de Juan Travnik). ¿Qué otros trabajos conocen que continúen esta serie de definiciones?

6. Pathos 2: El trabajo de Pablo Piovano El costo humano de los agrotóxicos es un trabajo documental contemporáneo con amplia circulación en medios de comunicación y espacios culturales, basado en una denuncia social y política que tiene como fin quemarnos, mostrarnos todo lo más crudo de la realidad de varias comunidades afectadas por los químicos y muestra, latente, el avance a zonas urbanas. ¿Recordamos otro trabajo documental o fotoperiodístico que tenga esta envergadura y circulación?

7. Pathos 3: Iconofilia -Iconofobia. Me pregunto: ¿esta división continúa hoy en día?. Es decir, ¿podemos encontrar estos dos bandos en el arte contemporáneo o en el periodismo contemporáneo? ¿ Recordemos el debate que abrió la imágen de Pablo Torres publicada en la tapa del diario El País el 12 de marzo de 2004. ¿En cuál de los dos bandos estaríamos nosotros?

8. Soma: Las y los artistas mencionados tienen distintas reflexiones explícitas o implícitas sobre el dispositivo que ponen en funcionamiento: el cuerpo ¿Qué diferencias notamos? ¿Podemos armar un árbol genealógico con ellas y ellos? ¿Podemos trazar vaso comunicantes entre sus estéticas? ¿Qué otras y otro artistas recuerdan que usen este mismo dispositivo?

9. Soma 2: Dividamos lo ejemplos en cuerpo manipulado, cuerpo intoxicado, cuerpo denuncialista, cuerpo disidente, cuerpo monstruoso.

10. Praxis: ¿Qué acercamientos tienen el documento audiovisual que acompaña las imágenes fotográficas de Pablo Piovano en El costo humano de los agrotóxicos con los 8 minutos de The sound of silence?

11. Praxis 2: reflexionemos sobre la propuesta de Jaar "Una foto no se toma: se hace” ¿En qué otros autores y en qué géneros podemos articular esta misma sentencia? ¿Cuándo una imágen es un documento y cuándo es una mercancía?

12. Walker Evans vs Pablo Piovano. Analicemos, con todas nuestras conclusiones el fotolibro "Elogiemos ahora a hombres famosos" (Evans-Agee) confrontado con "El costo humano de los agrotóxicos" ¿Encontramos distancias o acercamientos?

13. Una cita:

Verdaderas: las fotografías de Walker Evans lo son, con la discreción, el casi anonimato de quien, ante la simultaneidad de la belleza y de lo trágico reencontrado a cada paso, sabe hacerse a un lado para dejarle lugar en un testimonio tan elocuente como silencioso. ¿Arte como salvación? No, pero en el fondo, este llamado: que la ética y la estética concuerden.

La fotografía de Walker Evans es un arte que se borra, que renuncia a sí mismo como arte, para dar lugar a una necesidad diversa. Paradójicamente, es antes que nada por eso mismo que estas fotos son bellas y nos tocan justamente como figuras de arte (Pollok et al., p. 60, 2012). 


\title{
II. Lo que vemos nos mira: una lectura histórica de las imágenes de la historia. Hacia una pedagogía de lo no visible
}

\author{
Solo aquello que no deja de herir persiste en la memoria
}

Nietzsche

La humanidad también ha inventado en su extravío crepuscular, es decir, en el siglo XIX, el símbolo del recuerdo; ha inventado lo que hubiera parecido imposible; ha inventado un espejo dotado de memoria.

Walter Benjamin

Enseñar algo relacionado a la visión implica un debate sobre el sentido. Supone intervenir en una contienda sobre el sistema de significaciones culturales, políticas, e históricas. En nuestra praxis docente se pone de relieve el hecho de proponer afirmaciones, discutir premisas, sostener un discurso que le otorgue sentido a aquello que se analiza. Implica también saber trazar una serie de principios articulatorios, definir un campo de operaciones en relación con el objeto de estudio y en relación con el presente de su lectura.

En esa dirección llevé a cabo un análisis para poner de relieve cómo aproximarnos a la experiencia histórica desde las imágenes, cómo pensar su carácter de visibilidad específico a la vez que sus condiciones de producción y circulación, su fuera de marco. Esas clases sobre instantáneas de la memoria, me permitieron conocer y reconocer en el ágora áulica momentos en que, de repente, todos los que compartíamos el espacio integrábamos una familia mayor y otras voces poblaban nuestra memoria. Siempre vuelvo a unas páginas de Hannah Arendt, porque la política de ocultamiento de los crímenes de la dictadura había sido una parte esencial de la metodología represiva, así como también su política de visibilidad, y esa relación dialéctica entre ocultamiento y visibilidad podía quebrarse por intermedio de una mirada sostenida. La frase de Arendt es la siguiente,

A falta de verdad, encontramos sin embargo, instantes de verdad, y esos instantes son de hecho todo aquello de lo que disponemos para poner en orden en este caos del horror. Estos instantes surgen de repente, como un oasis en el desierto (Arendt, 2008).

¿Puede la práctica de la fotografía familiar y la reflexión acerca de la imagen fotográfica del álbum familiar, sus intervenciones, sus reproducciones, sus aperturas, proporcionar material para la historia de una generación perdida? La pregunta es una paráfrasis del conocido texto de Pierre Bourdieu (2003) sobre la fotografía como una posible herramienta para la investigación, y su actualización pone en escena el valor contemporáneo de las imágenes rescatadas del álbum familiar de la generación que fue diezmada durante la última dictadura argentina. Atendamos su reposicionamiento como documentos de la historia.

Retomar esta pregunta ante el panorama ofrecido por las producciones de Marcelo Brodsky, 1er, Año, 6ta División, de Gustavo Germano, Ausencias, y de Lucila Quieto, Arqueología de la Ausencia, autores que trabajé en clase repetidamente, arroja dos o tres conclusiones 
no solamente sobre la labor fotográfica en tanto técnica y estética, en tanto praxis, sino también sobre el proceso de revinculación de un país con su propia memoria y, por consecuencia, con su identidad. En clase teníamos un propósito explícito: conocer la constelación de los y las fotógrafas que producen sus obras sobre la problemática de representación de la generación diezmada por la última dictadura militar; pero también teníamos un currículum oculto: analizar las maneras en que la imagen opera ante la tragedia y develar cómo lo privado deviene público o, dicho mejor: cómo lo personal es político.

\section{La estática del álbum}

La primera etapa del soporte que llamamos álbum fotográfico familiar, tal como lo conocemos desde su auge en 1890 tiene una dinámica lineal y pautada ${ }^{8}$. Con un límite estructurado y un género establecido pone en suspenso todo juicio estético por la preponderancia de su estatismo y de la sacralidad que mantiene ante lo fotografiado y lo fotografiable.

Después de la segunda mitad del siglo XX, y ante la democratización de los dispositivos tecnológicos que permitió tener una cámara fotográfica al alcance de cualquier familia de clase media, la fotografía se vuelve un imperativo familiar (Sontag, 2002). Se integra a la vida interior de las familias, transforma en ceremonia, se hace rito. Allí, la familia en tanto pequeño núcleo de reproducción social, construye una crónica-retrato de sí misma. Confirma su pasado, reafirma su presente y se proyecta hacia el futuro. Dependiente de esta misma reproducción social es igual de estereotipada en sus convenciones: los encuadres, las poses, los acontecimientos fotografiados, los sujetos fotografiables, sus gestos, y sus formas de soporte: postales, cuadros, encuadernaciones que no se alejan de lo kitsch. ¿Hasta dónde, me pregunto, el soporte o dispositivo del álbum familiar, entonces, no es un elemento claustrofóbico, capitalista, eurocentrista? La respuesta esté tal vez en la permanencia del rito.

\section{Los usos alternativos de las imágenes}

Pensemos cómo el anclaje de la memoria tiene en la fotografía un basamento importante. De esto habla John Berger en su artículo "Los usos de la fotografía", cuando se pregunta “¿qué hacía las veces de la fotografía antes de la invención de la cámara fotográfica?”, su respuesta es directa: la memoria (Berger, 2012). Marxista pero inglés, la mirada de Berger es netamente romántica, idealista. En esto se diferencia de la corrosiva reflexión que Susan Sontag realiza en "La caverna de Platón", para quien (o contra quien, valdría decir) este texto está escrito. Sontag, discípula de Debord, ve en la fotografía del siglo XX el signo de la decadencia del hombre: lo atroz del dolor desenvuelto, la automatización del capitalismo representado en su click, la cosificación de los géneros y de la sexualidad. Para ella mirar es apuntar. En la lectura de Berger, el hecho de mirar debe ser un procedimiento más profundo, mirar es narrar y "solo lo que es capaz de narrar puede hacernos comprender" (Berger, 2012). El destino que le otorga a la fotografía es una función cargada de sentido político y cultural, revolucionaria y materialista, sino acaso mesiánica, Berger dice que: 
Es posible que la fotografía sea la profecía de una memoria social y política todavía por alcanzar. Una memoria así acogería cualquier imagen del pasado, por trágica que fuera, en el seno de su propia continuidad. Se trascendería la distinción entre los usos privado y público de la fotografía (Berger, 2012).

El uso alternativo de la fotografía es en Berger un uso comprometido que debería escapar de los ritos estáticos y condicionados de la sociedad para generar un gran álbum, una gran familia política, sin cortapisas con el mismo pasado apropiándose de los mismos muertos para "incorporarse a la memoria social y política" (Berger 2012). Lo que está en juego es restituirle a la fotografía el valor de poder narrar la experiencia política del hombre y su memoria social como perteneciente a una cultura global ${ }^{1}$, Berger aboga por restaurarle el valor reflexivo y de revelación. Porque aquí, la fotografía, volviendo a parafrasear otro texto, es la continuación de la memoria por otros medios. Y agrega,

Si los vivos asumieran el pasado, si este se convirtiera en una parte integrante del proceso mediante el cual las personas van creando su propia historia, todas las fotografías volverían a adquirir entonces un contexto vivo, continuarían existiendo en el tiempo, en lugar de ser momentos separados y anónimos (Berger, 2012).

¿Cómo proponer en clase que esos álbumes familiares incompletos son no sólo los de los artistas, no solo los de una generación, sino también los nuestros, los propios, así como quiere Berger? ¿Cómo integrarlos a nuestra propia biografía visual? Una posibilidad es crear un nosotros visual, una identidad común desde donde partir, ya que, como afirma Niedermaier, "las imágenes nos construyen a nosotros: imponen modos de conducta, condicionan experiencias y puntos de vista e incluso tratan de modelar" (2013). Las imágenes entonces están ligadas al propio devenir de la memoria colectiva de un país, a la memoria individual de una generación y a la memoria particular de un artista visual que encuentra en las fotos escolares una marca de las sangrientas políticas del gobierno dictatorial de ese período.

En este ejercicio de vasos comunicantes, la fotografía deja de ser una huella de lo real para ser una traza de lo real (Dubois, 2008), para ser su posible transformación. La propia visualidad no es simplemente un entorno físico o perceptivo, sino que constituye un complejo sistema de interacciones entre el sujeto y las imágenes presentes en su espacio social. La conformación de esta memoria a la que apunta Berger, cargada de significación política y cultural, no puede realizarse sino a partir de un uso alternativo de la fotografía, al que llamaremos, para remarcar su carácter híbrido, performático, y de esencia compleja: el artefacto de la imagen. Sigamos el mapa de territorios conceptuales y de construcciones posibles que ofrece Natalia Fortuny en su libro capital sobre el enlace de la fotografía y los tiempos de la dictadura. 


\section{La dinámica del artefacto de la imagen}

En su texto sobre las distintas representaciones fotográficas de la última dictadura argentina Natalia Fortuny pone en funcionamiento la lógica de los usos de la imagen y, extendiendo la potencialidad de su teorización, podemos desarrollar distintas instancias en cuanto a los usos de la imagen. Así, la periodística, icónica, netamente documental y utilitaria; la estática, anclada a su referencialidad pero que carga con una significación dentro su propio sistema; y un tercer uso que está marcado por la apertura de nuevas reflexiones sobre el discurso de la imagen: la imagen artefacto $^{10}$.

En las dos primeras clasificaciones, la imagen no sale de su función como registro social o íntimo y es principalmente icónica, envuelta en su propia retórica. Son imágenes no coleccionables, huellas, recortes de la realidad, en muchos casos llenas de anonimia. El movimiento interesante está en la tercera clasificación, donde se interviene en la gramática interna de la imagen la construcción de una narración. Se trata de la configuración intencional de una memoria generacional que en este caso está perdida. En el procedimiento de ensamble/yuxtaposición habita algo mucho más grande y significativo que las dos imágenes que se producen, hay algo dinámico cargado de sentido que funciona detrás del dispositivo que vemos. Sentimos el peso de la memoria que acude a completar el signo de esas ausencias. Ahí reside la extraña relación con lo real y con la memoria.

\section{Isotropías de la memoria}

El campo de la memoria de una generación es un terreno que no puede leerse de forma lineal. En este sentido, el discurso de la memoria no es isótropo (de un solo camino posible, de una sola dirección) puesto que, en palabras de Roland Barthes, "los bordes, las fisuras son imprevisibles", tanto en sus claudicaciones como en sus resistencias (Barthes, 2001). En el prólogo que abre Memory Works de Marcelo Brodsky, el filósofo Andreas Huyssen da pie a un nuevo concepto artístico, que sirve como hilo conductor para poder enlazar las imágenes de estos artistas, el de memory arts. Ahí Huyssen dice:

Proyectos como Nexo, de Marcelo Brodsky -artista también activo en el movimientos de Derechos Humanos-, pertenecen a la asombrosa emergencia en el arte post-minimalista y pertenecen a la asombrosa emergencia en el arte postminimalista y post-performance de lo que yo definiría tentativamente como memory art, un arte que hace memoria, práctica artística que se aproxima a prolongada y compleja tradición del art of memory, de las técnicas para recordar desarrolladas en formatos visuales, narrativos, retóricos (Huyssen, en Brodsky, 2003).

Las producciones de Germano, Quieto y Brodsky apelan a esta conceptualización. Sus producciones configuran una nueva práctica que "vulnera los límites de la instalación, fotografía, monumento y memorial” (Huyssen, en Brodsky, 2003) y alcanza, desde lo individual, una proyección hacia la comunidad. Huyssen también se detiene en que las obras 
de esta constelación de artistas consisten en gran medida en intervenciones manuales sobre soportes digitales y remarca que en esta yuxtaposición se supone el encuentro de la obra como documento, del artista y del espectador. En esta misma dirección, Alejandra Niedermaier completa la idea señalando que en este tipo de obras se imbrica la realidad y su representación cultural, "la imagen analógica representa, señala y muestra el mundo mientras que la imagen híbrida digital, señala, muestra y representa el pensamiento" (Niedermaier, 2015).

Estas imágenes, en tanto que artefactos fotográficos que enlazan las dinámicas de distintos soportes, nos pertenecen, apelan a los rasgos identitarios de la conformación de la memoria de un país, funcionan como testimonios de nuestra historia, ponen en escena el espectro de una memoria robada.

Es significativo, sintomático tal vez, que para acceder a la narración espectral de esa experiencia expropiada dentro de un espacio áulico, dentro del ágora que es el aula con estudiantes profesionales de la imagen como fue en mi caso, tengamos que hacernos cargo del extrañamiento que reproducen. En su ensayo sobre la imposibilidad de la narración de la catástrofe, Infancia e Historia, Agamben resalta que este extrañamiento consiste en poner de manifiesto su propia inexperimentabilidad.

Acceder a esta narración-umbral diacrónica, a esta extraterritorialidad propuesta por Germano y por Quieto "solo es posible mediante una destrucción” (Agamben 2010). La destrucción de la misma experiencia que se construye, en realidad, como lo inexperimentable ${ }^{11}$. Agamben se refiere a esta nueva conformación de la memoria como la "nueva morada del hombre moderno" (Agamben 2013). ¿Cómo no armar una pedagogía visual con esta constelación?

Es esencial para poner en movimiento este sistema de pensamiento que se activa con el problema de la representación dentro de un aula, puesto que, al término de su formación institucional en la Escuela de Fotografía, ellos mismos estarán trabajando en algún momento sobre estas definiciones. Para ser más claros, la puesta en escena del artefacto de la imagen no nace, en estos casos, a partir del trauma que significa la ausencia de esas personas en las imágenes, sino del trauma que significa completar/simbolizar esa ausencia.

\section{La imagen latente}

En esta misma dirección, François Soulages (2008) se detiene para reflexionar sobre aquello que pone de relevancia la unión de la imagen virtual y la analógica: lo inacabable. En el sentido ontológico de su generación estos artefactos fotográficos convocan dos imágenes, la imagen primera, la del desaparecido $o$ la desaparecida, y su potencialidad ${ }^{12}$ ante la frontera de la representación visual (Labraga 2016): la puesta en escena, la yuxtaposición de temporalidades. En el prólogo del libro de Quieto, Ana Longoni sintetiza que su trabajo provoca la irrupción de un tiempo imposible,

Que no nos llame a engaño la inscripción de una fecha en el margen de alguna foto (1963) ni el blanco y negro en el que se suman los planos. No se trata ni del tiempo pasado de las fotos ajadas de los pares ni del tiempo presente de las 
fotos de los hijos, ella misma lo nombra: el tercer tiempo, un tiempo inventado, onírico, ficcional, "una temporalidad propia" en la que puede ocurrir la ceremonia de encuentro (Longoni, en Quieto 2001).

"Imagen latente", dirá Soulages sobre aquellas imágenes que pueden ser producidas sobre la base de esta primera imagen de corte familiar. El entramado cultural (entendiendo "cultural" como historia, cultura y política) parte de lo emocional del deseo y recrea a través del testimonio del álbum el abrazo de dos generaciones. Significativo es, para terminar de demarcar esta latencia de una generación marcada por el hiato en esas fotografías familiares, el aviso clasificado que en 2001 hizo correr Lucila Quieto "Si querés tener la foto que siempre soñaste y nunca pudiste tener, ahora es tu oportunidad, no te la pierdas. Llamame" (Fortuny, 2014). Soulages, como en una proyección teórica sobre Arqueología de la Ausencia, trabajo del que no habla pero con el que está en una sorprendente consonancia, agrega "no hay una imagen latente única, sino una potencialidad de las imágenes latentes que será realizada, en primer lugar, de forma limitada en el negativo y, luego, sin límite, en la infinidad de fotos posibles" (Soulages, 2008). Concebidas de esta manera, el ensayo de Quieto es múltiple, dinámico, íntimo y público a la vez, pero también: infinito. El artefacto fotográfico que pone en movimiento la foto de ella con su padre se extiende a los 13 miembros de HIJOS que contiene su publicación de 2001.

Ausente/presente; acabado/inacabado; imagen en acto/imagen potencial e imagen latente, la ingeniería del artefacto fotográfico puesto en escena es mayor de lo que podemos imaginar ya que trabaja conceptos que debaten la validez del testimonio como prueba de la historia, la legitimidad de lo íntimo ante lo público.

Los tres a su manera, Marcelo Brodsky, Gustavo Germano y Lucila Quieto lograron entrever en los signos culturales, políticos, estéticos, de su propia época la concreta posibilidad de una sutura en el relato del pasado como acontecimiento. Los tres son exponentes de un movimiento de revisión crítica, de un intento de reescribir la gramática profunda de la identidad de la sociedad a través de la exposición de la memoria no como un relato lineal, sino como el resultado polisémico de una yuxtaposición. Si hay algo en común que se destaca en estas tres sintaxis de la memoria que nos proponen es la necesidad de aventurarse para que la obra sea capaz de preguntar, de interrogar, de mirar donde una sociedad no ve y construir una pedagogía de lo no visible. Al ser intervenidas de manera singular las fotografías minimalistas, estáticas, del álbum, de la credencial, adquieren dinamismo, un nuevo rol y una función política. Walter Benjamin afirma que sólo se aprende a conocer la conducta de una sociedad no cuando la recorremos en sus acciones diurnas, sino cuando por la noche "los viejos traperos, los vagabundos recorren los laberintos de la ciudad y recogen los desechos" dejados durante el día (Benjamin, 2010). Así también podemos pensar el camino de la revelación, del develamiento, de la memoria de un país, como un ejercicio que no se limite a observar una sociedad a partir de aquello que esa misma sociedad consagra como lo verdadero, como el relato esencial de su identidad, sino en tratar de pensar las grietas, las fallas, las fisuras, tratar de recorrer y reconocer con las armas de la crítica, y con el gran arma de la visualidad que ha sido y será la fotografía como artefacto en tanto trabaje conjuntamente kairos (acto), ujnos (huella), y tekné (técnica). Es decir, aquellos dispositivos de sentido que intenten dar cuenta y explicar la realidad de 
una generación. Estos elementos me acercaron ideas sobre la existencia pedagógica de lo no visible ante la lectura de documentos de la historia.

En la historia de la fotografía, en la historia de sus posibilidades técnicas, queda encerrada la posibilidad de una reflexión sobre los hechos más violentos de la historia contemporánea. Como docentes de la imagen, es nuestra tarea hacer presente estos planteos y poner en acto reflexivo y creativo las mismas escenas fragmentadas para dar a luz a una comunidad con ojo crítico que entienda en la imagen un arma de reconstitución social y de intervención política.

\section{Los discursos de la memoria}

La unión por el extrañamiento. La sutura por la imagen. La ruptura del automatismo estático del álbum familiar a partir del uso de imágenes que devienen en artefactos fotográficos. Pero este no es el único camino para la recomposición de la memoria. Existe otro tratamiento técnico usado en Argentina para llevar a cabo esta aproximación a la memoria de los desaparecidos, para establecer ese diálogo necesario por y pese a su imposibilidad. Me refiero al tratamiento poético, la sutura por la poesía, el lenguaje poético como campo de unión. No es aventurado pensarlo como el primer antecedente simbólico, lo que sí está claro es que ambos discursos son alternativas para completar ese doloroso álbum generacional.

Elijo dos poemas de los que vimos en el ágora áulica para ilustrar esto mismo, así leemos en Gelman,

Y los pedacitos rotos del sueño

¿se juntarán alguna vez?

¿se juntarán algún día,

Pedacitos?

¿Están diciendo que los enganchemos al tejido del sueño general?

(Gelman, 2010)

Y en "Otra cosa" de Paco Urondo,

Queridos hijitos, su papá poco sabe de ustedes

y sufre por esto. Quiero ofrecer un destino

luminoso y alegre, pero no es todo

y ustedes saben:

las sombras,

las sombras,

las sombras,

las sombras

me molestan y no las puedo tolerar.

Hijitos míos, no hay que ponerse tristes

por cada triste despedida: 
todas lo son, es sabido, porque hay otra partida, otra cosa,

digamos,

donde nada,

nada

está resuelto.

(Paco Urondo, 2010)

\section{Actividades:}

1. Los siguientes son artistas argentinos de distinta edades que trazaron en su obra la problemática de la frontera de representación (Labraga, 2015). Elegir uno de ellos y realizar un fichaje que comprenda el siguiente relevamiento: Biografía de Autor, Nombre de la obra, Año, Soporte, Lugar de Exposición, Hipótesis de lectura. Juan Travnik, Restos; Res, ¿Dónde están?; Hugo Aveta, Calle $30 n^{\circ}$ 1134; Fernando Gutierrez, Treintamil y Secuela; Helen Zout, Desapariciones; Inés Ulanovsky, ESMA y Fotos Tuyas; Paula Luttringer, El Matadero y El Lamento de los muros; Diego Aráoz, Santa Lucía; Gerardo Dell'Oro de Imágenes de la Memoria; Gabriela Bettini, Conversación con Antonio; Gustavo Dassoro - Soledad Nívoli, Cómo miran tus ojos; Verónica Maggi, El Rescate; Pedro Camilo Perez del Cerro, El viaje de Papá; Martín Costa ADN.

2. Las imágenes de Marcelo Ranea abren un campo de batalla ético en cuanto a la información mediática de los diarios y la realidad. ¿Qué contradicciones plantea?

3. Investigación: ¿qué otros autores latinoamericanos trabajan sobre el tópico de la memoria recuperada?

4. ARGRA: Según Cora Gamarnik las exposiciones de ARGRA fueron cruciales para perforar las modalidades del silencio que el régimen militar llevó a cabo en los medios de comunicación. ¿De qué exposiciones se trata?

5. ARGRA 2: en 2018 Argra publica el libro Aquí estuvimos. ¿Cómo podemos hacerlo funcionar en esta misma temática?

6. Definiciones: distintos teóricos se acercaron a la fotografía para remarcar que era, como afirma Fortuny sobre el trabajo de Quieto, "El futuro del pasado" y se hacen eco del cuerpo fantasmagórico de la fotografía. Elegir un texto y explicar por qué: Barthes en La cámara lúcida: "la fotografía como el reino de la contingencia, del spectrum, del fantasma que evoca lo ausente"; John Berger en "Los usos de la fotografía": "La huella es lo que estuvo ahí"; Susan Sontag en "La caverna de Platón": "la fotografía es un memento mori". 7. Barthes lee a Basterra. En La cámara lúcida, Roland Barthes desmenuza los conceptos de puntcum y studium. Miremos las imágenes que el fotógrafo sobreviviente del campo de concentración que funcionó en la Escuela de Mecánica de la Armada (ESMA) y separemos en cada una qué puede analizarse como punctum y qué puede ponerse en un hilo histórico como studium. 


\section{Desde el espectador emancipado hacia el estudiante emancipado}

Como vimos, el ejercicio de una política de la enseñanza diagramada a partir del reconocimiento de la fundamental relación entre lo visible y lo inteligible es un punto definitorio para quien quiera ejercer la docencia, puesto que esta relación es la que reconfigura los marcos sensibles en el régimen político donde una sociedad se define emancipada.

$\mathrm{Al}$ promediar la experimentación y viendo la buena recepción de distintos grupos de estudiantes de distintas disciplinas, me propuse listar una serie de buenas prácticas que hacían que la carga teórica y conceptual de las clases tengan el suficiente dinamismo para que alumnas y alumnos no formados teóricamente puedan seguir el desarrollo de las exposiciones, estas son algunas:

1. La construcción de un pensamiento lo suficientemente heterogéneo como para representar las voces del grupo y lo suficientemente crítico como para poder ponerlo en uso en distintas situaciones.

2. La consideración de que la incertidumbre del alumno sobre su saber tiene que convertirse en un motor y no en una parálisis.

3. El hecho de desmantelar las prácticas corporales, pasar de la exposición al taller o al debate, comenzar con desarrollos teóricos de manera inductiva, plantear exposiciones de los alumnos, privilegiar su propio recorrido en la formación de la imagen: usar sus conocimientos adquiridos como vasos comunicantes entre materias. Si como apunta Walter Benjamin, "no hay percepción que no esté impregnada de recuerdos" vehiculizar esos recuerdos que pertenecen a la biografía curricular del aula para poner en movimiento temas de la unidad.

4. Darle intencionalidad y lugares determinados en el CV a la experimentación en la producción de sentido. Es decir, integrar dentro de las clases los sucesos político - sociales del entorno.

Una imagen nunca cuenta una sola historia. Una imagen es la sumatoria de dos relatos, la del momento de su toma y la del momento de su lectura. Así mismo, la docencia puede ser pensada por la sumatoria de dos tiempos: el tiempo en donde un eje teórico práctico es planificado y un tiempo en donde es puesto en práctica.

En estos dos momentos inciden tanto la mirada del estudiante como el recorte del docente. En estas dos temporalidades teóricas y prácticas recaen distintas maneras de encuadrarse en el mundo y de pensarse como identidades manifiestas: lo que hacemos, los contenidos, las maneras, las inflexiones hablan de nosotros de la misma manera que cuando en la génesis de una obra artística un escultor decide mármol, bronce o madera. En docencia, como en las imágenes que la historia del arte trabaja: lo que vemos, nos mira.

Así la política del arte está hecha del entrelazamiento de tres lógicas: la del trabajo en la alfabetización artística, la de las estrategias metapolíticas de formación de comunidad y la de las formas de experiencia estética a partir del reconocimiento de una praxis fotográfica resultante del giro ético del arte contemporáneo (Escobar 2015).

La combinatoria de distintas prácticas transversales que atomicen lo cultural o lo teórico con lo práctico, Frigerio dice sobre esto que "la rigurosidad de los saberes, posibilita la 
inteligencia de la combinatoria entre praxis, teoría, estética, producción y vida cotidiana -ya que- el arte es una manera de pensar, de dar a conocer, de compartir y de repartir" (Frigerio 2012).

Este entrelazamiento implica también un trenzado singular. Ese ahí donde funciona el trabajo de la alfabetización artística. No es sobre el análisis de un mundo imaginario opuesto al real, sino el análisis de obras que producen disenso, que cambia los modos de presentación sensible y la formas de enumeración al cambiar los marcos, las escalas o los ritmos educativos, al construir relaciones nuevas entre la apariencia y la realidad, entre lo singular y lo común, lo visible y su significación (Niedermaier, 2013). Este trabajo y su puesta en práctica dentro de mis clases cambió las coordenadas de lo representable; cambió nuestra percepción de los acontecimientos sensibles, nuestra manera de relacionarlos con sujetos, la manera en la que nuestro mundo es poblado de acontecimientos y figuras.

Comprender desde el aula Las estrategias de los artistas que se proponen cambiar las referencias de aquello que es visible y enunciable, de hacer ver aquello que no era visto, de hacer ver de otra manera aquello que era visto demasiado fácilmente, de poner en relación aquello que no lo estaba, con el objetivo de producir rupturas en el tejido sensible de las percepciones y en la dinámica de los afectos.

Lo emergente de la imagen alude a los nuevos significados y valores, nuevas prácticas, nuevas relaciones y tipos de relaciones que se crean permanentemente, una estética relacional no ya del arte (Nicolas Bourriaud, 2014) sino de la alfabetización artística, o su puesta en práctica.

Didier Anzieu, nombrado por Graciela Frigerio, afirma que el hecho de crear requiere como primera condición una filiación simbólica ya que produce filiaciones y paternidades. Me planteé en la asignatura cómo hacer surgir estas filiaciones teniendo en cuenta las distintas identidades de los distintos grupos que tuve a cargo, sin olvidar que Anzieu aclara que, "ofrecer filiaciones múltiples es el mayor apuntalamiento estético que la educación ofrece a los sujetos, y esta transmisión no puede pensarse como una estética no independiente de una ética" (Frigerio, 2012).

Por eso mismo el proceso de aprendizaje está siempre conectado con los andamiajes de la memoria y de la identidad, nada sucede fuera del triángulo de la subjetividad íntima en la articulación con el panorama social y la cobertura de la esfera plástica cronotopológica. Hay un tiempo y un lugar para determinado planteo de temas. No fue lo mismo llevar adelante clases con una lectura de género en el Sistema de la Visualidad contemporánea antes que después del desbordamiento de la marea verde; no fue lo mismo abordar las temáticas de los Derechos Humanos en un país con un claro horizonte de políticas de la memoria que en otro donde estaban borroneadas y confundidas acaso intencionalmente. El fin de la alfabetización artística tal como lo entiendo, es la de trastocar las coordenadas de lo representable y así generar nuevas subjetividades contemporáneas insertas en la complejidad del tejido artístico.

Siguiendo a Niedermaier en "Cuando me asalta el miedo, creo una imagen" (2015) podemos establecer un proceso de imbricación entre la praxis creativa del productor artístico y la praxis selectiva del docente en tanto creador y curador de contenidos didácticos y disciplinares de una asignatura. Como espigadores, en cuanto a las tramas intertextuales que tejen y a los recortes que realizan para consignar un currículum y organizar sus materiales, 
las y los docentes de una materia de análisis visual aúnan un punto de vista técnico, un punto de vista estético, un punto de vista ideológico y un punto de vista didáctico. En la materialidad de sus ideas, en la forma de extenderlas al alumnado, en la adaptación de los contenidos existe un tratamiento plástico donde se fragua un conocimiento con marcas de la experiencia personal tanto como de sus propias presunciones e investigaciones si acaso las tuvieran ${ }^{13}$.

La doble cara de esto es que "si se considera a la enseñanza como una propuesta personal de intervención -el subrayado es propio- (...) la pedagogía de la imagen resulta un permanente constructo que debe ser revisado periódicamente" (Frigerio, 2012).

Entonces, de la misma manera que una obra se modifica en el tiempo, los proyectos didácticos piden asimismo una revisión dinámica de sus propósitos y objetivos para ser adecuados a su entorno.

De esta forma, los lenguajes artísticos visuales se entrelazan y convierten al espectador en plausible autor, la esfera de la docencia engloba tanto al docente como al estudiante: "el conocimiento entre el docente y en el discente. Al envolverlos, los incluye en la escena. Esa inclusión implica el involucramiento, el compromiso de los -docente, alumno-realizador visual" (Niedermaier, 2015).

En este sentido, la lógica del espectador emancipado ante las perspectivas del arte contemporáneo puede trasladarse a la del alumno emancipado ante las perspectivas de las nuevas pedagogías en donde colabora con el docente y con el proyecto de la materia generando a partir de disparadores pedagógicos nuevas narrativas o líneas de fuga.

Roland Barthes hace un movimiento análogo cuando intercede por el valor del sentido de los textos a partir de la visión del lector. Se plantea así este giro en la centralidad del texto que, mediando la Escuela de la Recepción, deja de otorgarle el exorbitante privilegio a la obra para hacer hincapié en donde la obra se dispersa, es decir, en la plural actividad de su lectura y quebrar el hecho consumado de que:

El autor está consolidado como eterno propietario de su obra y nosotros, los lectores, como simples usufructuantes. Esta economía implica evidentemente un tema de autoridad el autor tiene derechos sobre el lector, lo obliga a coptar un determinado sentido de la obra (...) de ahí procede la moral crítica del recto sentido y, por ende, del contra sentido (Barthes, 2003).

¿No nos habla aquí Barthes de una pedagogía de la lectura? ¿No fueron sus escritos sobre la muerte del autor un punta pié para fundar una pedagogía disidente, de la dispersión de sentidos, de la diseminación de sentencias, de lógica asociativa y de una verdad lúdica aunque igual de identitaria?

Graciela Frigerio, al notar este cruce de lugares afirma que "si la transmisión -de sentido a través de las imágenes que generamos- sostiene una lectura de lo sensible y lo inteligible, entonces la transición no puede pensarse como una estética no independiente de una ética" (Frigerio, 2012).

Y esta visión se continúa con el fragmento de cita que Niedermaier elige de Agamben, dándole a la imagen un sentido de ubicuidad "la imagen fotográfica es siempre más que una imagen: es el lugar de un descarte, de una laceración sublime entre lo sensible y lo 
inteligible, entre la copia y la realidad, entre el recuerdo y la esperanza" (Agamben en Niedermaier, 2014).

Como si el mapa precediera al territorio, la conformación del universo de lo inteligible y de lo sensible está articulada por los distintos caminos de la visualidad contemporánea, así cada una de las esferas se repliega o se desenvuelve sobre las posibilidades teóricas y técnicas que a su propio entorno le corresponde. Frigerio incluye a Legéndre cuando realiza el binomio conceptual de imágenes/sociedad, como condición de posibilidad elemental para construir una subjetividad que permita construir las distintas dimensiones de la convivencia humana, de un cómo vivir juntos ${ }^{14}$,

Para que haya sociedad es necesario que trabaje la fábrica de imágenes que nos permitan construir, ver al otro como semejante y al sujeto como diferenciado, vivir entre otros, con otros, no es sino el efecto de una producción estética (Frigerio, 2012).

Como afirma Frigerio, entonces, la relación que se sucede entre las esferas de lo inteligible y lo sensible siempre ha interrogado al hombre, más que nada porque significa un escenario para la propia convivencia y para la propia visión de un mundo a través de una praxis docente.

Viviana Suarez, elige hablar de una pedagogía de la interferencia al desentrañar sus prácticas dentro del ámbito posmoderno o sobre-moderno del arte contemporáneo, generando un traspaso de saberes que,

Implique una fricción, en última instancia, entre los campos del hacer y el saber, entre praxis y episteme; ejercicio de una interferencia en la fluidez interdisciplinaria. Porque de eso se trata, en definitiva, un campo -con sus interrogantes, sus búsquedas, sus incertezas- desbarate al otro, lo cuestione, lo suspenda y a la vez lo movilice (Suárez 2016).

La interferencia que esgrime busca una fricción para crear actividades que se alejen del modelo del maestro/profesor como pilar asimétrico que tiene, retiene y valida una manera de pensar conformada por la verdad para abrir paso al modelo del pedagogo que, desde su etimología presupone un camino (paidos, niño; ago, conducir), es decir, un proceso para la elaboración del pensamiento. Este modelo quiebra la tradicional imagen del docente activo y del estudiante pasivo y de un flujo unidireccional de los conocimientos, concepción que dialoga con lo antes dicho por Barthes ante la importancia del lugar del lector como principal aportante de sentido. ¿Hasta dónde oímos a nuestros alumnos y nuestras alumnas en el contexto áulico donde convivimos? Tal vez una clave de esta mirada resida también en la necesidad de cambiar nuestro lenguaje como docentes: puesto que transformar el sentido común significa entre otras cosas, transformar el lenguaje que vehiculizamos. No puede ser la voz del docente el único idioma válido dentro de la clase. El desafío de una educación emancipadora es el de desnaturalizar los lugares de poder de una lengua consumada y devolverla a nuestra cotidianidad para verla en funcionamiento con sus grises y contradicciones. 
Ubicarse como garante de conocimiento implica necesariamente establecer una división jerárquica entre uno y otros que, en última instancia, exhibe una forma intangible de dominación, en palabras de Foucault,

Hay efectos de verdad que una sociedad como la occidental produce a cada instante. Se produce el efecto de la verdad. Esas producciones de verdad no pueden disociarse del poder y de los mecanismos de poder, porque estos últimos hacen posibles esas producciones de verdades (Foucault, 2012).

Transmitir, nos dicen, es un vicio de quienes han quedado atrapados en la melancolía, una pérdida de tiempo allí donde lo que se vuelve legítimo e impredecible es lo por venir, las nuevas tecnologías, el marketing educativo. La intemperie de nuestra época se manifiesta en esos desfondamientos y en esas rupturas que alejan a las generaciones entre sí, bloqueando la posibilidad de diálogo y, por lo tanto, de un intercambio genuino que pueda fundarse en lo que viene de lejos y en aquello otro que aportan los recién llegados.

No dejé de pensar en este juego de rupturas y de suturas que para tramar tejidos, textos, apuntes sueltos como una retahíla de perlas en un collar, tampoco dejé de pensar y, para poner en escena esta intemperie repetida, en la alentadora frase que le escribió a Max Horkheimer su amiga Salka Viertel en los oscuros años de exilio y guerra:

Frente a lo que está irrumpiendo actualmente sobre Europa y, tal vez sobre el mundo entero, (...) nuestro trabajo actual está destinado esencialmente a ser transmitido a través de la noche venidera: una suerte de mensaje dentro de una botella.

\section{Conclusión}

Pienso que hay en la búsqueda constante del docente y del artista algo del signo de la errancia, del caminante o del explorador.

Luego de la formación del postítulo no dejé de tomar cada una de mis clases como una nueva instancia para cambiar, para renovar, para dejar de lado la pose que aprendí en otras instituciones y convertir el aula en un foro de discusión, en un lugar donde se pueda discutir y poner en relevancia distintas problemáticas que nos ayudaban a avanzar en el proceso crítico de revelar y de rebelar los intereses de la iconósfera en la que vivimos. Es decir, de desmantelar y de sublevar llevando a cabo un proceso espiralado de la construcción del conocimiento bajo la misma pregunta repetida desde distintos vértices de la cultura visual: ¿qué significan las imágenes que vemos?

La sorpresa, pienso, es un atributo que se le brinda sin más al nómade, un diamante que encuentra solamente el que se aventura a un terreno inexplorado. La docencia puede ser leída como una poética urbana, con su maraña de flujos, nudos, redes, como la posibilidad de una conexión incesante. 
Un día analizando noticias sobre femicidio y tratando de desmontar la ideología machista imperante, Daniela, una alumna de la carrera, nos contó que una de sus vecinas había sido víctima de la violencia de género y que varias vecinas la acompañaron a hacer la denuncia; otro día, mientras proyectaba distintos trabajos fotográficos sobre la dictadura y su representación, Bárbara, otra alumna de la carrera, nos contó que un familiar de su madre es uno de los desaparecidos de esa represión militar, nos dijo que no hay en su casa cartas ni fotos del primo Daniel; en otra ocasión mientras leíamos poemas de Gelman y de Paco Urondo donde había un largo responso sobre los amigos secuestrados Laura, otra alumna de la carrera, nos dijo "no puedo creer todavía que ellos tenían nuestra edad cuando los desaparecieron". Ese día leímos los textos adjuntos a las imágenes de la obra de Paula Luttringer El lamento de los muros y la detallada entrevista que Denise Labraga le hizo a artistas que tienen en su obra el eje de la representación del horror. Ahí, las palabras del docente Ramiro Larraín acercaba los tiempos, las temporalidades. Lo que veíamos en clase seguía vivo en el mismo contexto educativo, las alumnas podían salir del aula y continuar esa entrevista, ese convivio con la historia reciente del país.

En una de esas charlas, Ramiro me contó de su relación con sus maestros: León Ferrari y Juan Carlos Romero. Esta era una lección extra curricular que me estaba dando, una lectura íntima de sus propias fuentes, y algo que él continuaba en su incesante prédica por la libertad, por la conformación de una identidad, y por comprometerse políticamente con esos chicos que tenía enfrente y a los que le dedicaba su tiempo y todo su espacio.

Continué esas charlas con otros compañeros a quienes consideraba relevantes, así me enteré que todos ellos también habían tenido un maestro secreto, alguien de quien imitar al menos la entrega absoluta a la docencia y sus mandamientos contradictorios. Entonces pensé que siempre es así, que los docentes que amamos nos sirven de consuelo y de ejemplo a menudo sin que ellos mismos lo sepan siquiera y que en ese sentido son tan imaginarios como los bocetos de sus clases, las intrínsecas conexiones con que responden a cada comentario o las lejanas tierras que pueblan.

En 1973, Joseph Beuys inauguró en Kassel el primer cuatrimestre de la institución llamada Universidad Internacional Libre con una obra llamada Bomba de miel. Teniendo en cuenta el inadvertido proceso de formación de la cera y de la miel, Beuys estableció una conexión entre las abejas y una comunidad educativa en plena colaboración a partir de la miel, orgánica y cristalina y fluye como el pensamiento. Para Beuys la miel puede ser agresiva, mortal, puede permanecer inerte y puede moldearse con vitalidad, la miel puede estar en todos lados.

Amplificado al arte, la miel abarca a cada hombre en cada capa de la sociedad, ya que no hay nada fuera del circuito económico (la escuela donde las y los docentes trabajamos, la universidad donde estudiamos, la industria donde nuestros padres, nosotros o nuestros alumnos trabajan, los medios de comunicación que nos informan) no hay nada fuera del sistema educativo que él proponía en esas clases: su relación con todos los aspectos cotidianos y su fuerza productiva es transformadora: evolucionaria y revolucionaria, dirá Beuys. Como las históricas jornadas de la Experiencia de Rosario llevadas a cabo a partir de 1958 por Enrique Pichón-Riviére, Beuys reunió en los cien días que duró la Bomba de miel, a boxeadores, industriales, obreros, artistas, profesionales y alumnos de todas las carreras de Europa. Heinrich Boll, quien acompañó teóricamente este proyecto, afirmó que su inten- 
ción era la supresión de los límites dentro del aula. Esta idea se opone a la clásica versión escolar donde los cuerpos son disciplinados con reglamentos y tecnologías de supresión regidos por la producción laboral: de lo que se trata ahí, en el modelo secular, es de sacar de los cuerpos de los y las estudiantes el máximo provecho estático.

Pero Beuys afirmó en 1988, cuando lo erradicaron de Alemania y viajó a norteamérica, que su mayor obra de arte había sido la docencia y también, que todo hombre es democráticamente creativo, que todo hombre es un artista, solo basta poner en funcionamiento la miel y tejer las estructuras del panal. Hagamos eso.

\section{Notas}

1. Susan Sontag en Ante el dolor de los demás inserta un ejemplo ilustrativo de este aparato inquebrantable: en octubre de 2001 el Ministerio de Defensa estadounidense dispuso la desaparición visual de las consecuencias de los bombardeos sobre Kabul, la capital de Afganistán. Adquirió, entonces, la exclusividad de los derechos de publicación sobre todas las imágenes satelitales de Afganistán y los países vecinos (Sontag, 2005, 79). Como si la guerra no consistiera solamente en incendiar ciudades y poblaciones, sino en el borramiento de esas imágenes. Evidentemente este ejemplo señala una construcción visual de lo social, de lo que podemos ver, de lo que nos dejan ver. Una construcción artificial y política. Una simulación, en términos de Jean Baudrillard.

2. Así como Sontag (Sontag, 2002, 18) y Joly (Joly, 2010, 25) se centran en lo que desarrollan como el Sistema de las Imágenes, Jonathan Crary (2003, 245 y ss) en su célebre capítulo "Regímenes escópicos de la modernidad" del libro Campos de Fuerza. Entre la Historia Intelectual y la Crítica Cultural, prefiere la idea de Régimen Escópico puesto que incluye en la historia de la evolución de las imágenes la historia social de los avances técnicos que la producen.

3. Usamos este término porque refiere tanto a la imagen como al imaginario que forja.

4. En este sentido, Gubern se acerca a la concepción de Régimen Escópico de Crary donde el aspecto técnico no es independiente de la evolución del Aparato Visual, sino que está incluído en sus movimientos y en sus ampliaciones.

5. Decimos aquí "plástica" literal y figurativamente: en primer lugar porque es maleable de sentido y en segundo lugar porque hace referencia al campo artístico de las artes visuales en su conjunto.

6. Georges Didi-Huberman (2017) realiza un mapeo de cómo fueron cambiando las posiciones culturales y filosóficas del concepto de pathos a través de la historia occidental, desde los griegos donde suponía un padecer activo hasta el siglo XX donde supone un caldo de cultivo para distintas revueltas sociales en Einsestein o Pasolini.

7. Pensemos en la crítica que desarrolla Theodor Adorno sobre la propaganda nazi "La propaganda fascista ataca a espectros más que a opositores reales, es decir, construye una imagen del judío, o del comunista, y la destroza, sin preocupare por las correspondencias entre estas imágenes y la realidad" (Adorno, 2010). 
8. La fecha indicial es 1888 cuando George Eastman comienza la fabricación de cámaras "portables" e introduce así la fotografía en el ámbito privado. En la estación "Peru" del subterráneo de línea "A" en la Ciudad de Buenos Aires todavía perduran los avisos publicitarios de estas nuevas cámaras.

9. No olvidemos que Berger es marxista y tiene una mirada internacionalista en cuanto a los procesos del arte. Sin embargo, el camino de Edward Steichen en The Family of Man no sería el más correcto para esta internacionalización, porque "Lamentablemente, el atajo tomado por Steichen a la hora de tratar, como si fuera una familia, un mundo dividido por clases, hizo que el conjunto de la exposición, no necesariamente cada foto por separado, tuviera un inevitable carácter sentimental y satisfecho de sí mismo. La verdad es que la mayoría de las fotos de personas tienen que ver con el sufrimiento, y la mayor parte del sufrimiento es producido por le hombre" (Berger 2012, p 77).

10. Ante esto, una salvedad: la teoría no resuelve todo, la teoría lo problematiza todo. El sentido de la aparición de este concepto dentro del texto es doble. Por un lado hacer connotar el nuevo y distinto uso contemporáneo de las fotografías de corte familiar dentro del panorama de las visualidades latinoamericanas (un ejemplo claro de esto es que el trabajo de Germano Ausencias, tiene su continuación en Chile y en Brasil). Por otro lado, el uso de un nuevo término remarca la necesidad de renombrar un objeto de estudio y no seguir apelando a él como "fotografía familiar". Tal vez sea el momento de avanzar un casillero epistemológico y, porque no, ontológico a la hora de abordar los fenómenos del producto fotográfico posmoderno. Es así, entonces, que seguiremos conceptualmente el texto de Natalia Fortuny, puesto que se nutre de Walter Benjamin para referirse en estos casos de producción fotográfica como "artefacto de la imagen".

11. O experimentable dentro de un juego de espejos o temporalidades, como dice Natalia Fortuny "Lucila ve el futuro. No el de hoy sino el del pasado" (Fortuny, 2015).

12. En esta línea de análisis y visualizaciones, es preciso nombrar el libro que también analizamos en distintas cursadas de la materia El siluetazo, coordinado por Ana Longoni y Gustavo Bruzzone y editado por Adriana Hidalgo.

13. Sobre este tópico de la renovación, un joven Pierre Bourdieu escribía en su manifiesto sobre la educación universitaria (escrito junto con Jacques Derrida y otros personajes del Collége) que las currículas deberían ser lo suficientemente flexibles y actualizables como para organizar y permitir investigaciones por parte de los alumnos y los docentes (Bourdieu, 2014).

14. En una de los intercambios docentes que mantuve con Ramiro Larraín, a raíz de cómo adaptaba las metodologías de sus clases para un nuevo grupo me contestó: "estamos hablando y realizando práctica de estudio simples pero importantes para saber cómo podemos vivir juntos en esta materia ellos como grupo consolidado y nosotros como docentes de una comunidad reflexiva".

\section{Bibliografía}

Adorno, T. (2015). Teoría Estética. Buenos Aires: Las cuarenta. 
. (2010). Sobre la propaganda Fascista. Buenos Aires: Paradiso.

Agamben, G. (2014). ¿Qué es un dispositivo? Buenos Aires: Adriana Hidalgo.

Agamben, G. (2012). "Infancia e Historia”, en Infancia e Historia. Buenos Aires: Adriana Hidalgo.

Arendt, H. (2008). Los procesos de la historia. Barcelona: AKAL.

Barthes, R. (1968). "Retórica de la imagen” en Elementos de semiología. Barcelona: Seix Barral. . (2003). "Escribir la lectura" en Sobre la lectura. Buenos Aires: Phaidos. . (2003). El placer del texto. Buenos Aires: Siglo XXI.

Benjamin, W. (2010). La obra de arte en tiempos de su reproductibilidad técnica. Buenos Aires: Cuenco de Plata.

Berger, J. (2012). Mirar. Buenos Aires: De la Flor.

Bourdieu, P. (2014). "9 principios para una reflexión sobre los contenidos de la enseñanza", en Capital cultural, escuela y espacio social. Buenos Aires: Siglo XXI.

Bourdieu, P. (2003). La fotografía, un arte intermedio. Barcelona: GG.

Cámara, M. (2011). Cuerpos Paganos. Buenos Aires: Santiago de Arcos.

Crary, J. (2003). Campos de fuerza. Entre la historia intelectual y la crítica cultural. Buenos Aires: Phaidos.

Debord, G. (2012). La sociedad del espectáculo. Buenos Aires: La marca editora.

Didi-Huberman, G. (2007). "La emoción no dice 'yo"” en La política de las imágenes. Santiago de Chile: Metales pesados.

. (2017). ¡Qué emoción! ¿Qué emoción? Buenos Aires: Capital intelectual.

Dubois, P. (2008). El acto fotográfico. Buenos Aires: La Marca editora.

Escobar, T. (2015). Imagen e intemperie. Las tribulaciones del arte en los tiempos del mercado total. Buenos Aires: Capital Intelectual.

Foucault, M. (2012). "Poder y saber" en El poder, una bestia magnifica. Buenos Aires: Siglo XXI.

Fortuny, N. (2015). Memorias fotográficas. Imagen y dictadura en la fotografía argentina contemporánea. Buenos Aires: La Luminosa.

Frigerio G. (2012). “Grülp” en Educar: sobre impresiones estéticas. Buenos Aires: Del estante.

García Canclini, N. (1990). Culturas híbridas: Estrategias para entrar y salir de la modernidad. México: Grijalbo.

Gelman, J. Notas. Página 12, Buenos Aires, 2010.

Guillén, C. (2001). Ensayos de Literatura Comparada. México: FCE.

Giunta, A. (2014). ¿Cuándo comienza el arte contemporáneo? Catálogo ArteBA 2014.

González, H. (2010). "Mármol, imagen y martirio" en Memory Works. Marcelo Brodsky. Universidad de Salamanca, Salamanca.

Gubern R. (2004). Patologías de la imagen. Barcelona: Anagrama. . (1996). Del bisonte a la realidad virtual. Barcelona: Anagrama.

Jakobson, R. (1985). Cuestiones de poéticas. México: FCE.

Jaar, A. “The sound of silence. Quiero sugerir que las imágenes no son inocentes” entrevista radial en la radio chilena Cooperativa TV. Consultado última vez en marzo 2019, https:// www.youtube.com/watch? $\mathrm{v}=\mathrm{qGzCUYwakWE}$

Jameson, F. (2004). El Giro Cultural. Barcelona: Manantial.

Joly, M. (2010). Introducción al análisis de las imágenes. Buenos Aires: La Marca. 
Labraga, D. (2016). "Fronteras Blandas. Posibilidades de representación del horror" en Niedermaier, A. y Soulages, F. (comp.) La experiencia fotográfica en relación a la experiencia del mundo, Cuaderno $n^{\circ} 66$, Universidad de Palermo.

Montes, A. (2017). De los cuerpos travestis a los cuerpos zombis. El cuerpo como figura de la historia. Buenos Aires: Argus-a.

Niedermaier A. (2015). "Cuando me asalta el miedo, creo una imagen”, en Goyes Narváez, J. C. y Niedermaier, A. (comp.). Poéticas y Pedagogías de la imagen, Cuaderno $n^{\circ} 56$, Universidad de Palermo.

. (2013). "La distribución de lo inteligible y lo sensible hoy", en Niedermaier, A. y Polo, V. (comp.) Acerca de la subjetividad contemporánea, Cuaderno $n^{\circ} 43$, Universidad de Palermo.

Ranciére, J. (2007). “El teatro de las imágenes” en La política de las imágenes. Santiago de Chile: Metales pesados.

. (2010). El espectador emancipado. Barcelona: Manantial.

. (2016). Aisthesis. Barcelona: Manantial.

Sontag, S. (2002). Sobre la fotografía. Buenos Aires: Alfaguara.

. (2003). Ante el dolor de los demás. Buenos Aires: Alfagura.

Suarez, V. (2016). "Interferencias. Notas sobre el taller como territorio, la regla como posibilidad, la obra como médium" en Pedagogías y poéticas de la imagen $\mathrm{N}^{\circ} 56$ Goyes Narváez, J. C. y Niedermaier, A. (comp.) Buenos Aires, Cuadernos del Centro de Estudios en Diseño y Comunicación, Universidad de Palermo.

Soulages, F. (2008). “Para una nueva filosofía de la imagen”, en Revista de Filosofía y teoría Política, 2008, n39, pp. 95-120.

Abstract: This work will try to assemble different pedagogical journeys generating con-
cepts and integrating experiences that show the need to rethink the paradigms of visual
education from an open and interdisciplinary point of view.

Keywords: Contemporary visual didactics - Subjective educational processes - phatos soma.

Resumo: Este trabalho procurará reunir diferentes caminhos pedagógicos, gerando conceitos e integrando experiências que marcam a necessidade de repensar os paradigmas da educação visual de um ponto de vista aberto e interdisciplinar.

Palavras chave: Didática da visualidade contemporânea - Fotografia e práxis histórica mídia gráfica - processos educativos de subjetivação - Iconosfera contemporânea - phatos visual - soma visual.

[Las traducciones de los abstracts fueron supervisadas por el autor de cada artículo] 